\title{
Review of Pre- and Post-1980 Buildings in CBECS - HVAC Equipment
}

DW Winiarski

W Jiang

MA Halverson

December 2006

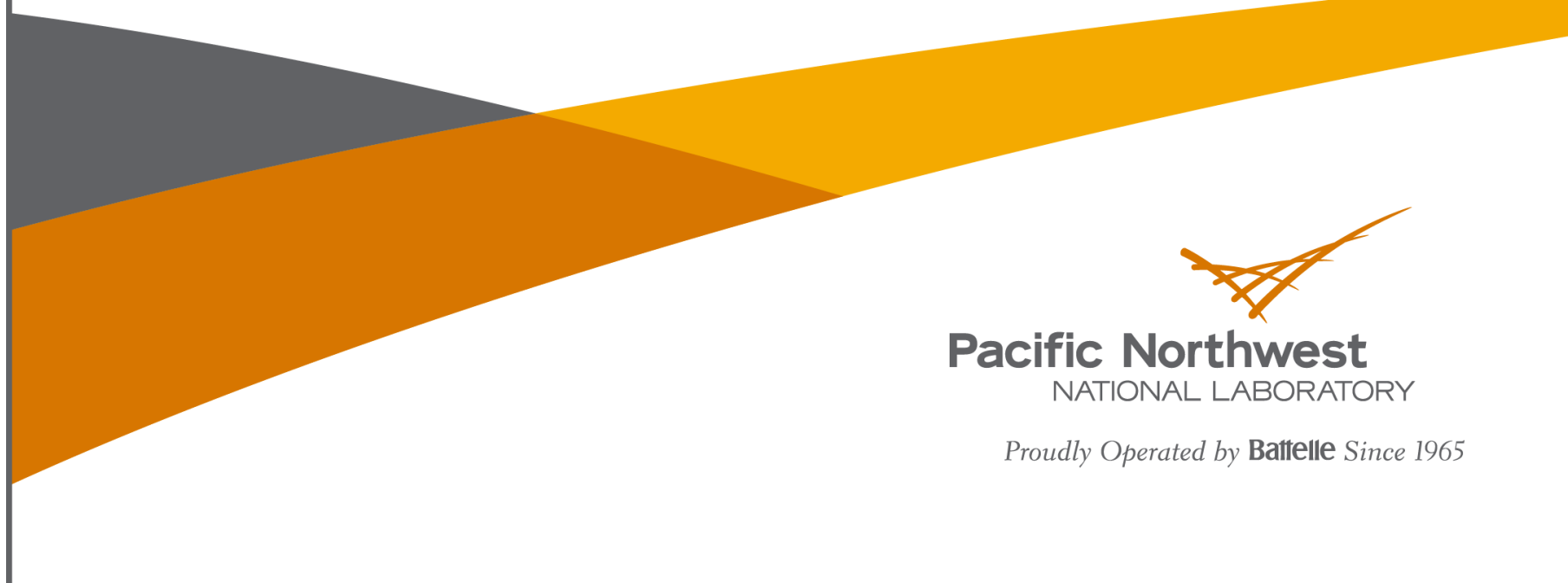




\title{
DISCLAIMER
}

This report was prepared as an account of work sponsored by an agency of the United States Government. Neither the United States Government nor any agency thereof, nor Battelle Memorial Institute, nor any of their employees, makes any warranty, express or implied, or assumes any legal liability or responsibility for the accuracy, completeness, or usefulness of any information, apparatus, product, or process disclosed, or represents that its use would not inf ringe privately owned rights. Reference herein to any specific commercial product, process, or service by trade name, trademark, manufacturer, or otherwise does not necessarily constitute or imply its endorsement, recommendation, or favoring by the United States Government or any agency thereof, or Battelle Memorial Institute. The views and opinions of authors expressed herein do not necessarily state or reflect those of the United States Government or any agency thereof.

\author{
PACIFIC NORTHWEST NATIONAL LABORATORY \\ operated by \\ BATTELLE \\ for the \\ UNITED STATES DEPARTMENT OF ENERGY \\ under Contract DE-AC05-76RL01830
}

Printed in the United States of America
Available to DOE and DOE contractors from the
Office of Scientific and Technical Information
P.O. Box 62, Oak Ridge, TN 37831-0062;
ph: (865) 576-8401
fax: $(865) 576-5728$
email: reports@adonis.osti.gov

Available to the public from the National Technical Information Service

5301 Shawnee Rd., Alexandria, VA 22312

ph: (800) 553-NTIS (6847)

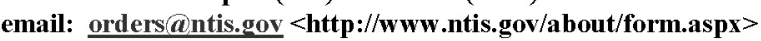

Online ordering: http://www.ntis.gov

This document was printed on recycled paper. 


\section{Review of Pre- and Post-1980 Buildings in CBECS - HVAC Equipment}

DW Winiarski

W Jiang

MA Halverson

December 2006

Prepared for

the U.S. Department of Energy

under Contract DE-AC05-76RL01830

Pacific Northwest National Laboratory

Richland, Washington 99352 



\section{Summary}

This report analyses the content of the 2003 Commercial Building Energy Consumption Survey (CBECS) (DOE EIA 2003) to determine the most typical heating, ventilating, and air-conditioning (HVAC) equipment in use in 15 different building types. Two sets of recommended HVAC systems are developed - one for post-1980 buildings and one for pre-1980 buildings. The recommendations are listed below in tables S-1 and S-2.

Table S-1. PNNL Recommendations for Post-1980 Buildings - HVAC Equipment

\begin{tabular}{clcc}
\hline & \multicolumn{1}{c}{ Type } & \multicolumn{2}{c}{ PNNL Recommendation } \\
\cline { 3 - 4 } Number & & Heating & Cooling \\
\hline 1 & Large Office & Boiler & Chiller \\
2 & Medium Office & Furnace & PACU \\
3 & Small Office & Furnace & PACU \\
4 & Warehouse & Furnace & PACU \\
5 & Stand-alone Retail & Furnace & PACU \\
6 & Reserved (strip mall) & NA & NA \\
7 & Primary School & Boiler & PACU \\
8 & Secondary School & Boiler & Chiller \\
9 & Grocery Store & Furnace & PACU \\
10 & Fast Food & Furnace & PACU \\
11 & Restaurant & Furnace & PACU \\
12 & Hospital & Boilers & Chillers \\
13 & Outpatient Health Care & Furnace & PACU \\
14 & Motel & ISH & IRAC \\
15 & Hotel & Boiler & Chiller \\
\hline PACU - Packaged Air Conditioning Unit & ISH - Individual Space Heater & \\
IRAC - Individual Room Air Conditioner & NA - Not Available & \\
\hline
\end{tabular}

Table S-2. PNNL Recommendations for Pre-1980 Buildings - HVAC Equipment

\begin{tabular}{clcc}
\hline & & \multicolumn{2}{c}{ PNNL Recommendation } \\
\cline { 3 - 4 } Number & & Heating & Cooling \\
\hline 1 & Large Office & Boiler & Chiller \\
2 & Medium Office & Furnace & PACU \\
3 & Small Office & Furnace & PACU \\
4 & Warehouse & Furnace & PACU \\
5 & Stand-alone Retail & Furnace & PACU \\
6 & Reserved (strip mall) & NA & NA \\
7 & Primary School & Boiler & PACU \\
8 & Secondary School & Boiler & PACU \\
\hline
\end{tabular}




\begin{tabular}{clll}
\hline 9 & Grocery Store & Furnace & PACU \\
10 & Fast Food & Furnace & PACU \\
11 & Restaurant & Furnace & PACU \\
12 & Hospital & Boilers & Chillers \\
13 & Outpatient Health Care & Furnace & PACU \\
14 & Motel & ISH & IRAC \\
15 & Hotel & Boiler & Chiller \\
\hline PACU - Packaged Air Conditioning Unit & ISH - Individual Space Heater & \\
IRAC - Individual Room Air Conditioner & NA - Not Available & \\
\hline
\end{tabular}




\section{Acronyms and Abbreviations}

$\mathrm{AC}$

CAV

CBECS

DOE

EER

FCU

HP

HVAC

IRAC

ISH

ISH

$\mathrm{MZ}$

NA

PACU

PHU

PNNL

PTAC

PTHP

Res. AC

SZ

VAV air conditioning

constant Volume

commercial Buildings Energy Consumption Survey

U.S. Department of Energy

energy efficiency ratio

fan coil units

heat pump

heating, ventilating, and air conditioning

individual room air conditioners

individual space heater

individual space heaters

multi-zone

not available

packaged air conditioning units

packaged heating units

Pacific Northwest National Laboratory

packaged terminal air conditioner

packaged terminal heat pump

residential air conditioner

single zone

variable air volume 



\section{Contents}

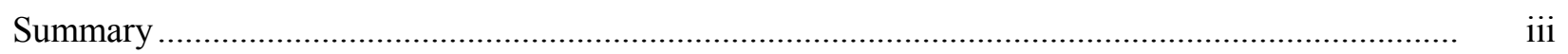

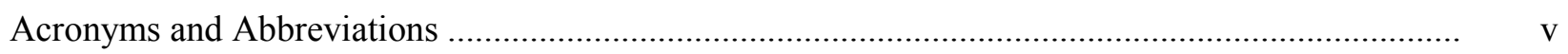

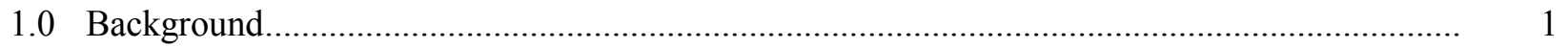

2.0 HVAC Information Available in CBECS...................................................................... 1

3.0 CBECS Limitations in Terminology ............................................................................. 2

4.0 CBECS Limitations on Percent of Floor space Heated and Cooled......................................... 3

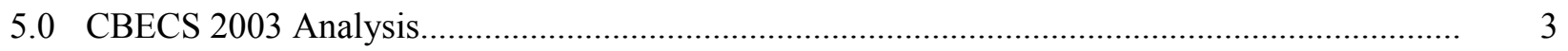

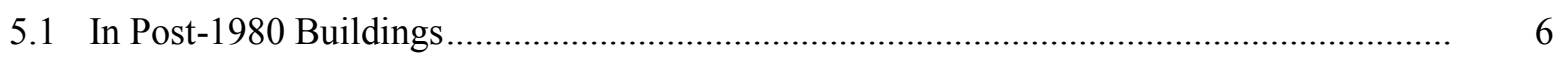

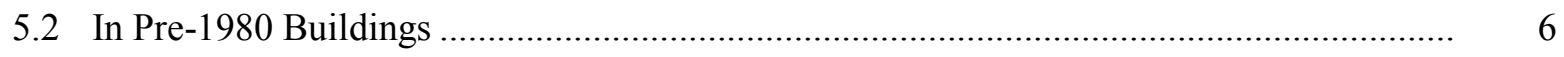

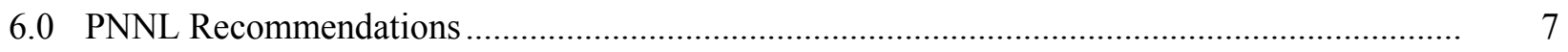

\section{Tables}

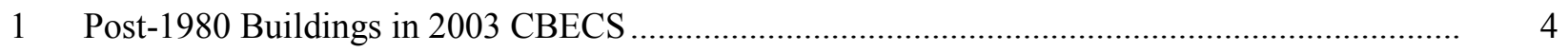

2 Pre-1980 Buildings in 2003 CBECS.............................................................................. 5

3 PNNL Recommendations for Post-1980 Buildings - HVAC Equipment ................................. 7

4 PNNL Recommendations for Pre-1980 Buildings - HVAC Equipment.................................... 8

5 Total Floor space in Buildings Reporting Use of VAV Systems ......................................... 9

6 PNNL Recommendations for Post-1980 Buildings - HVAC Equipment and Air Distribution... 10

7 PNNL Recommendations for Pre-1980 Buildings - HVAC Equipment and Air Distribution .... 11 



\subsection{Background}

The U.S. Department of Energy (DOE) tasked Pacific Northwest National Laboratory (PNNL) with analyzing heating, ventilating, and air conditioning (HVAC) systems and equipment for DOE's Reference Buildings ${ }^{1}$ based on 2003 Commercial Buildings Energy Consumption Survey (CBECS) (DOE EIA 2003) data. This report summarizes the results of PNNL's analysis of 2003 CBECS data and provides PNNL's recommendations for HVAC systems and equipment for use in the Reference Buildings.

\subsection{HVAC Information Available in CBECS}

Useful information regarding heating and cooling equipment is available in the CBECS dataprimarily in the main cooling equipment and main heating equipment fields. For each building in the CBECS survey, the responder was asked to identify the main cooling and main heating equipment. The categories for response are as follows:

- main cooling equipment

- central chillers inside the building

- district chilled water

- heat pumps for cooling

- individual room air conditioners (IRAC)

- packaged air conditioning units (PACU)

- residential type central air conditioners

- swamp coolers or evaporative coolers

- some other cooling equipment

- main heating equipment

- boilers inside the building

- district steam or hot water

- furnaces that heat air directly

- heat pumps for heating

- individual space heaters (ISH)

- packaged heating units (PHUs)

- some other heating equipment

CBECS also presents data on the percentage of each building heated and cooled based on survey response, as well as the percentage heated or cooled (assumed to here refer to \% floor space) by specific equipment categories. The latter data collected are in a similar form to the main cooling and main heating categories:

- percent cooled by:

- PACU

- Central AC

\footnotetext{
${ }^{1}$ DOE Reference Buildings were developed as part of DOE's Commercial Building Initative. The Reference buildings provide typical building models for approximately $70 \%$ of the commercial buildings in the US. See http://www1.eere.energy.gov/buildings/commercial_initiative/reference buildings.html for more detail.
} 
- IRAC

- Heat pumps

- District chilled water

- Central chillers

- Swamp coolers

- Other cooling equip

- percent heated by:

- Furnace

- Boiler

- PHU

- ISH

- Heat pumps

- District steam/hot water

- Other heating equip

Where heat pumps are used, the survey asks additional questions regarding the type of heat pumps (e.g., water source, ground source, air source, packaged, split system, individual room) used for heating and cooling in the building. CBECS also presents data on whether the building uses a variable air volume (VAV) system and the main and secondary heating or cooling fuel types.

\subsection{CBECS Limitations in Terminology}

Unfortunately, not all the CBECS responses regarding equipment categories are mutually exclusive. Two potential responses in particular that can cause trouble are PHUs and IRACs.

CBECS defines a "packaged unit" as a type of heating and/or cooling equipment assembled at a factory and installed as a self-contained unit. Packaged units are in contrast to engineer-specified equipment built from individual components and specifically designed for use in a given building. Some types of electric packaged units are also called direct expansion (DX) units. While this definition exists in the CBECS 2003 glossary, the responses captured in the survey are for packaged cooling units or PHUs. PHUs are simply "boxes that provide heating" to many occupants. Identifying what that box is, be it a furnace, a boiler, or a heat pump, is beyond the interest or knowledge of some occupants, and so PHU could also mean any of these three categories. The most common PHU is expected by the authors to be a gas furnace installed as part of packaged rooftop cooling unit. However, hydronic coils could also be installed for heating.

CBECS defines a "furnace" as a type of space-heating equipment with an enclosed chamber where fuel is burned or electrical resistance is used to heat air directly, without using steam or hot water. Air ducts then distribute the heated air throughout the building. However, a furnace reply could refer to a gas or electric furnace in a packaged rooftop unit, a standalone gas or electric furnace, or a gas or electric furnace with a direct expansion coil—as with a residential split system furnace/air handler.

Based on these two definitions, it is clear that a large overlap exists between the categories of PHU and furnace that cannot be easily disaggregated through other survey responses. 
Individual (room) air conditioner is another term that could cause some confusion in earlier versions of CBECS (such as DOE EIA 1995), as responders showed some uncertainty regarding whether packaged terminal air conditioners (PTACs) should be classed under IRAC or packaged cooling units. The 2003 CBECS clarifies that IRACs are direct expansion units (as opposed to fan coil units [FCU]) and that all packaged terminal equipment is clearly to be categorized as IRAC or individual room heat pumps.

Heat pump is another term that was more problematic in previous versions of CBECS. In the 2003 CBECS, the definitions and follow-on questions help to identify the various classes of heat pumps. In the case of certain equipment types, heat pumps will overlap with other buildings heating or cooling equipment (e.g., water source heat pump systems commonly require boilers and in many cases chillers). Heat pumps can potentially also be interpreted as package heating units.

\subsection{CBECS Limitations on Percent of Floor Space Heated and Cooled}

While CBECS does provide estimates of the fraction of floor space heated or cooled by the different equipment categories, analysis of the data shows that it is quite common for the sum of the estimates to exceed 100 percent (around 14 percent of the post-1980 buildings exceed 100 percent for heating equipment). For simple buildings, it may be relatively easy to define one heating or cooling equipment type for each portion of floor space such that this is not an issue. However, for other buildings with multiple systems serving multiple spaces or with poorly defined or unknown zoning, assigning a floor area to a particular system may be very difficult.

\subsection{CBECS 2003 Analysis}

To examine HVAC system selection, PNNL extracted data for all 2003 CBECS buildings in two sets - construction in 1980 and before and construction post-1980. Tables 1 and 2 show the result of this extraction. The tables show the most common HVAC types by Reference building type ${ }^{2}$, viewed on both number of represented buildings and on total represented floor area.

Table 1 exhibits two special points of interest (in bold text): the high percentage of unheated and uncooled warehouses and the significant fraction of district heating and cooling in secondary schools.

Table 2 exhibits three special points of interest (in bold text): the high percentage of unheated and uncooled warehouses, the significant fraction of district heating and cooling in secondary schools and hospitals, and the surprising large segment of hospitals that report other cooling systems than those explicitly identified in the CBECS survey.

\footnotetext{
${ }^{2}$ This analysis uses the U.S. National Renewable Energy Laboratory approach for defining Large, Medium, And Small Offices, with Small referring to one story, Medium referring to two to four stories, and Large referring to greater than four stories. Other methods of categorizing these would presumably influence the relative equipment usage statistics for these office benchmarks
} 
Table 1. Post-1980 Buildings in 2003 CBECS

\begin{tabular}{|c|c|c|c|c|c|}
\hline \multirow[b]{2}{*}{ Number } & \multirow[b]{2}{*}{ Type } & \multicolumn{2}{|c|}{ By Number of Buildings } & \multicolumn{2}{|c|}{ By Floor Area } \\
\hline & & Heating & Cooling & Heating & Cooling \\
\hline 1 & Large Office & $\begin{array}{l}\text { Boiler 40\% } \\
\text { PHU 20\% } \\
\text { District 7\% }\end{array}$ & $\begin{array}{l}\text { PACU 43\% } \\
\text { Chiller 39\% } \\
\text { District 5\% }\end{array}$ & $\begin{array}{l}\text { Boiler 29\% } \\
\text { PHU 18\% } \\
\text { District } 16 \%\end{array}$ & $\begin{array}{l}\text { Chiller } 50 \% \\
\text { PACU } 27 \% \\
\text { District } 12 \%\end{array}$ \\
\hline 2 & $\begin{array}{l}\text { Medium } \\
\text { Office }\end{array}$ & $\begin{array}{l}\text { Furnace 34\% } \\
\text { PHU 25\% } \\
\text { HP 23\% }\end{array}$ & $\begin{array}{l}\text { PACU 39\% } \\
\text { Res AC 25\% } \\
\text { HP 23\% }\end{array}$ & $\begin{array}{l}\text { PHU 30\% } \\
\text { Boiler 22\% } \\
\text { Furnace } 18 \%\end{array}$ & $\begin{array}{l}\text { PACU 59\% } \\
\text { HP 14\% } \\
\text { Chiller } 11 \%\end{array}$ \\
\hline 3 & Small Office & $\begin{array}{l}\text { PHU 39\% } \\
\text { Furnace 33\% } \\
\text { HP 20\% }\end{array}$ & $\begin{array}{l}\text { PACU } 43 \% \\
\text { Res AC 33\% } \\
\text { HP 20\% }\end{array}$ & $\begin{array}{l}\text { PHU 38\% } \\
\text { Furnace 32\% } \\
\text { HP 19\% }\end{array}$ & $\begin{array}{l}\text { PACU } 49 \% \\
\text { Res AC } 26 \% \\
\text { HP } 18 \%\end{array}$ \\
\hline 4 & Warehouse & $\begin{array}{l}\text { None 57\% } \\
\text { Furnace 19\% } \\
\text { PHU 10\% }\end{array}$ & $\begin{array}{l}\text { None 61\% } \\
\text { PACU 17\% } \\
\text { Res AC 13\% }\end{array}$ & $\begin{array}{l}\text { Furnace } 29 \% \\
\text { PHU } 27 \% \\
\text { None } 27 \%\end{array}$ & $\begin{array}{l}\text { PACU 45\% } \\
\text { None } \mathbf{2 6 \%}\end{array}$ \\
\hline 5 & $\begin{array}{l}\text { Stand-alone } \\
\text { Retail }\end{array}$ & $\begin{array}{l}\text { Furnace } 43 \% \\
\text { PHU } 31 \%\end{array}$ & $\begin{array}{l}\text { PACU } 42 \% \\
\text { Res AC } 28 \% \\
\end{array}$ & $\begin{array}{l}\text { PHU } 42 \% \\
\text { Furnace } 30 \%\end{array}$ & PACU $73 \%$ \\
\hline 6 & $\begin{array}{l}\text { Reserved } \\
\text { (strip mall) }\end{array}$ & No Data & No Data & No Data & No Data \\
\hline 7 & $\begin{array}{l}\text { Primary } \\
\text { School }\end{array}$ & $\begin{array}{l}\text { PHU } 28 \% \\
\text { Furnace } 28 \% \\
\text { HP } 16 \% \\
\text { ISH } 10 \% \\
\text { Boiler } 9 \%\end{array}$ & $\begin{array}{l}\text { PACU 36\% } \\
\text { Res AC 21\% } \\
\text { HP 17\% } \\
\text { Chiller 9\% }\end{array}$ & $\begin{array}{l}\text { Boiler 32\% } \\
\text { HP 23\% } \\
\text { PHU } 18 \% \\
\text { Furnace } 15 \%\end{array}$ & $\begin{array}{l}\text { PACU 37\% } \\
\text { Chiller 26\% } \\
\text { HP 18\% } \\
\text { Res AC } 10 \%\end{array}$ \\
\hline 8 & $\begin{array}{l}\text { Secondary } \\
\text { School }\end{array}$ & $\begin{array}{l}\text { Furnace } 27 \% \\
\text { HP } 24 \% \\
\text { PHU } 17 \% \\
\text { Boiler } 11 \% \\
\text { District 10\% }\end{array}$ & $\begin{array}{l}\text { HP 24\% } \\
\text { PACU 21\% } \\
\text { Chiller 14\% } \\
\text { District } \mathbf{1 2 \%}\end{array}$ & $\begin{array}{l}\text { Boiler } 37 \% \\
\text { District } \mathbf{2 0 \%} \\
\text { Furnace } 13 \% \\
\text { PHU } 12 \% \\
\text { HP } 9 \%\end{array}$ & $\begin{array}{l}\text { Chiller } 37 \% \\
\text { PACU } 21 \% \\
\text { District } 20 \% \\
\text { HP } \mathbf{1 0 \%}\end{array}$ \\
\hline 9 & Grocery Store & $\begin{array}{l}\text { PHU } 42 \% \\
\text { Furnace } 37 \%\end{array}$ & $\begin{array}{l}\text { PACU 56\% } \\
\text { Res AC } 15 \%\end{array}$ & $\begin{array}{l}\text { Furnace } 47 \% \\
\text { PHU } 45 \%\end{array}$ & $\begin{array}{l}\text { PACU } 68 \% \\
\text { Res AC } 10 \%\end{array}$ \\
\hline 10 & Fast Food & $\begin{array}{l}\text { PHU } 60 \% \\
\text { Furnace } 24 \%\end{array}$ & $\begin{array}{l}\text { PACU } 73 \% \\
\text { Res AC. } 22 \%\end{array}$ & $\begin{array}{l}\text { PHU } 63 \% \\
\text { Furnace } 20 \%\end{array}$ & $\begin{array}{l}\text { PACU 74\% } \\
\text { Res AC 24\% }\end{array}$ \\
\hline 11 & Restaurant & $\begin{array}{l}\text { PHU 43\% } \\
\text { Furnace } 28 \%\end{array}$ & PACU 64\% & $\begin{array}{l}\text { PHU 51\% } \\
\text { Furnace } 24 \%\end{array}$ & PACU 65\% \\
\hline 12 & Hospital & Boiler $71 \%$ & $\begin{array}{l}\text { Chiller 54\% } \\
\text { PACU 33\% }\end{array}$ & Boilers $69 \%$ & $\begin{array}{l}\text { Chiller 68\% } \\
\text { PACU 13\% }\end{array}$ \\
\hline 13 & $\begin{array}{l}\text { Out Patient } \\
\text { Health Care }\end{array}$ & $\begin{array}{l}\text { Furnace } 43 \% \\
\text { PHU 22\% HP } \\
21 \% \\
\text { Boiler 9\% } \\
\end{array}$ & $\begin{array}{l}\text { PACU } 40 \% \\
\text { Res AC 36\% } \\
\text { HP } 21 \%\end{array}$ & $\begin{array}{l}\text { Furnace } 28 \% \\
\text { PHU 23\% HP } \\
22 \% \text { Boiler } \\
22 \% \\
\end{array}$ & $\begin{array}{l}\text { PACU } 43 \% \\
\text { HP } 23 \% \\
\text { Res AC 19\% }\end{array}$ \\
\hline 14 & Motel & $\begin{array}{l}\text { ISH } 43 \% \\
\text { HP } 26 \%\end{array}$ & $\begin{array}{l}\text { IRAC } 60 \% \\
\text { HP } 23 \%\end{array}$ & $\begin{array}{l}\text { ISH } 36 \% \\
\text { HP } 22 \%\end{array}$ & IRAC 55\% \\
\hline 15 & Hotel & $\begin{array}{l}\text { ISH } 45 \% \\
\text { HP } 19 \% \\
\text { Boiler } 12 \%\end{array}$ & $\begin{array}{l}\text { IRAC } 47 \% \\
\text { HP } 18 \% \\
\text { Chiller } 11 \%\end{array}$ & $\begin{array}{l}\text { Boiler } 44 \% \\
\text { ISH } 21 \%\end{array}$ & $\begin{array}{l}\text { Chiller 39\% } \\
\text { IRAC 25\% }\end{array}$ \\
\hline $\begin{array}{l}\text { PACU - Pr } \\
\text { IRAC - Inc } \\
\text { PHU - Pac }\end{array}$ & $\begin{array}{l}\text { aged Air Condi } \\
\text { idual Room Air } \\
\text { ged Heating Un }\end{array}$ & $\begin{array}{l}\text { oning Unit } \\
\text { Conditioner }\end{array}$ & $\begin{array}{l}\text { ISH - Ind } \\
\text { Res AC }- \\
\text { HP }- \text { Hea }\end{array}$ & $\begin{array}{l}\text { dual Space He } \\
\text { esidential Air C } \\
\text { ump }\end{array}$ & ditioner \\
\hline
\end{tabular}


Table 2. Pre-1980 Buildings in 2003 CBECS

\begin{tabular}{|c|c|c|c|c|c|}
\hline \multirow[b]{2}{*}{ Number } & \multirow[b]{2}{*}{ Type } & \multicolumn{2}{|c|}{ By Number of Buildings } & \multicolumn{2}{|c|}{ By Floor Area } \\
\hline & & Heating & Cooling & Heating & Cooling \\
\hline 1 & $\begin{array}{l}\text { Large } \\
\text { Office }\end{array}$ & $\begin{array}{l}\text { Boiler 63\% } \\
\text { District 17\% }\end{array}$ & $\begin{array}{l}\text { Chiller 52\% } \\
\text { PACU 23\% }\end{array}$ & $\begin{array}{l}\text { Boiler 53\% } \\
\text { District 28\% }\end{array}$ & $\begin{array}{l}\text { Chiller 66\% } \\
\text { PACU 20\% }\end{array}$ \\
\hline 2 & $\begin{array}{l}\text { Medium } \\
\text { Office }\end{array}$ & $\begin{array}{l}\text { Furnace } 45 \% \\
\text { Boiler } 22 \% \\
\text { PHU } 14 \%\end{array}$ & $\begin{array}{l}\text { PACU 36\% } \\
\text { Res AC 33\% } \\
\text { IRAC } 13 \%\end{array}$ & $\begin{array}{l}\text { Boiler } 32 \% \\
\text { Furnace } 26 \% \\
\text { PHU } 20 \%\end{array}$ & $\begin{array}{l}\text { PACU } 43 \% \\
\text { Res AC } 17 \% \\
\text { Chiller } 16 \%\end{array}$ \\
\hline 3 & $\begin{array}{l}\text { Small } \\
\text { Office }\end{array}$ & $\begin{array}{l}\text { Furnace } 51 \% \\
\text { PHU } 25 \%\end{array}$ & $\begin{array}{l}\text { PACU } 42 \% \\
\text { Res AC } 35 \% \\
\text { IRAC } 10 \%\end{array}$ & $\begin{array}{l}\text { PHU 38\% } \\
\text { Furnace 36\% }\end{array}$ & $\begin{array}{l}\text { PACU } 61 \% \\
\text { Res AC } 18 \%\end{array}$ \\
\hline 4 & Warehouse & $\begin{array}{l}\text { Furnace 33\% } \\
\text { None } 32 \%\end{array}$ & $\begin{array}{l}\text { None } 47 \% \\
\text { PACU } 21 \%\end{array}$ & $\begin{array}{l}\text { Furnace 34\% } \\
\text { ISH 13\% } \\
\text { Boiler 13\% } \\
\text { None 12\% } \\
\end{array}$ & $\begin{array}{l}\text { PACU 33\% } \\
\text { None 32\% }\end{array}$ \\
\hline 5 & $\begin{array}{l}\text { Stand-alone } \\
\text { Retail }\end{array}$ & $\begin{array}{l}\text { Furnace } 52 \% \\
\text { PHU } 15 \%\end{array}$ & $\begin{array}{l}\text { PACU } 43 \% \\
\text { IRAC } 19 \% \\
\text { Res AC } 19 \%\end{array}$ & $\begin{array}{l}\text { Furnace } 48 \% \\
\text { PHU } 18 \% \\
\text { Boiler } 8 \%\end{array}$ & $\begin{array}{l}\text { PACU } 48 \% \\
\text { IRAC } 15 \% \\
\text { Res AC } 13 \%\end{array}$ \\
\hline 6 & $\begin{array}{l}\text { Reserved } \\
\text { (strip mall) }\end{array}$ & No Data & No Data & No Data & No Data \\
\hline 7 & $\begin{array}{l}\text { Primary } \\
\text { School }\end{array}$ & $\begin{array}{l}\text { Boiler 33\% } \\
\text { PHU 25\% } \\
\text { Furnace 24\% }\end{array}$ & $\begin{array}{l}\text { PACU 36\% } \\
\text { IRAC 23\% } \\
\text { HP 9\% }\end{array}$ & $\begin{array}{l}\text { Boiler 61\% } \\
\text { PHU 17\% } \\
\text { Furnace 14\% }\end{array}$ & $\begin{array}{l}\text { PACU 33\% } \\
\text { IRAC } 22 \% \\
\text { Chiller } 18 \%\end{array}$ \\
\hline 8 & $\begin{array}{l}\text { Secondary } \\
\text { School }\end{array}$ & $\begin{array}{l}\text { Furnace 27\% } \\
\text { Boiler } 20 \% \\
\text { District } \mathbf{1 7 \%} \\
\text { PHU } 12 \% \\
\text { ISH } 12 \%\end{array}$ & $\begin{array}{l}\text { IRAC 26\% } \\
\text { PACU 25\% } \\
\text { Res AC 12\% } \\
\text { HP 11\% } \\
\text { Chillers } 8 \% \\
\text { District 6\% }\end{array}$ & $\begin{array}{l}\text { Boiler } 54 \% \\
\text { District } 21 \%\end{array}$ & $\begin{array}{l}\text { PACU 33\% } \\
\text { Chiller } 26 \% \\
\text { IRAC } 15 \% \\
\text { District } \mathbf{1 1 \%}\end{array}$ \\
\hline 9 & $\begin{array}{l}\text { Grocery } \\
\text { Store }\end{array}$ & $\begin{array}{l}\text { Furnace } 32 \% \\
\text { None } \mathbf{2 5 \%} \\
\text { ISH } 14 \%\end{array}$ & $\begin{array}{l}\text { PACU } 39 \% \\
\text { Res AC } 18 \% \\
\text { IRAC } 13 \%\end{array}$ & $\begin{array}{l}\text { Furnace } 38 \% \\
\text { PHU } 30 \%\end{array}$ & $\begin{array}{l}\text { PACU } 61 \% \\
\text { Res AC } 16 \%\end{array}$ \\
\hline 10 & Fast Food & $\begin{array}{l}\text { PHU } 42 \% \\
\text { HP } 16 \%\end{array}$ & $\begin{array}{l}\text { PACU } 60 \% \\
\text { HP } 16 \%\end{array}$ & $\begin{array}{l}\text { PHU 59\% } \\
\text { HP } 14 \%\end{array}$ & PACU $68 \%$ \\
\hline 11 & Restaurant & $\begin{array}{l}\text { Furnace } 53 \% \\
\text { PHU } 20 \%\end{array}$ & $\begin{array}{l}\text { PACU } 47 \% \\
\text { Res AC } 26 \%\end{array}$ & $\begin{array}{l}\text { Furnace } 47 \% \\
\text { Boiler } 21 \% \\
\text { PHU } 20 \%\end{array}$ & $\begin{array}{l}\text { PACU } 45 \% \\
\text { Res AC } 21 \%\end{array}$ \\
\hline 12 & Hospital & Boilers 76\% & $\begin{array}{l}\text { Chillers } 39 \% \\
\text { Other } \mathbf{2 6 \%}\end{array}$ & $\begin{array}{l}\text { Boilers } 76 \% \\
\text { District } 17 \%\end{array}$ & $\begin{array}{l}\text { Chillers 58\% } \\
\text { District 12\% } \\
\text { Other } 12 \%\end{array}$ \\
\hline 13 & $\begin{array}{l}\text { Out Patient } \\
\text { Health Care }\end{array}$ & $\begin{array}{l}\text { Furnace } 53 \% \\
\text { PHU } 17 \%\end{array}$ & $\begin{array}{l}\text { PACU } 46 \% \\
\text { Res AC } 39 \%\end{array}$ & $\begin{array}{l}\text { Boiler } 33 \% \\
\text { Furnace } 32 \% \\
\text { PHU } 14 \%\end{array}$ & $\begin{array}{l}\text { PACU } 46 \% \\
\text { Res AC 33\% }\end{array}$ \\
\hline 14 & Motel & $\begin{array}{l}\text { ISH } 37 \% \\
\text { PHU 27\% } \\
\text { Boiler 23\% }\end{array}$ & $\begin{array}{l}\text { IRAC } 45 \% \\
\text { PACU } 28 \%\end{array}$ & $\begin{array}{l}\text { ISH } 37 \% \\
\text { Boiler 23\% } \\
\text { PHU } 21 \% \\
\end{array}$ & $\begin{array}{l}\text { IRAC } 52 \% \\
\text { PACU } 20 \%\end{array}$ \\
\hline 15 & Hotel & $\begin{array}{l}\text { Boiler } 32 \% \\
\text { PHU } 24 \% \\
\text { ISH } 21 \%\end{array}$ & $\begin{array}{l}\text { IRAC } 46 \% \\
\text { PACU } 30 \%\end{array}$ & $\begin{array}{l}\text { Boiler 37\% } \\
\text { PHU } 14 \% \\
\text { Furnace 13\% }\end{array}$ & $\begin{array}{l}\text { Chiller 45\% } \\
\text { IRAC 33\% }\end{array}$ \\
\hline
\end{tabular}


IRAC - Individual Room Air Conditioner

PHU - Packaged Heating Unit
Res AC - Residential Air Conditioner

HP - Heat Pump

As discussed, it is difficult to draw a clear distinction between PHUs and furnaces and to some extent between PHUs and heat pumps. Judging from the CBECS responses and PNNL's findings, PHU and furnace should be considered synonymous. However, where the building use might indicate a large fraction of heat pumps, some non-trivial fraction of the PHUs may be, in fact, heat pumps. In addition, when considering the use of district cooling or district heating, PNNL believes that for the purposes of developing the benchmarks, the most important consideration is that these systems are hydronic systems. If the primary heating or cooling equipment source (boiler or chiller) is assumed to be in the building such that we can capture the energy efficiency of that equipment when modeling, then these district systems are probably best categorized by lumping district cooling with chillers and district heating with boilers.

Based on Table 1, PNNL recommends using the heating and cooling equipment that has the highest fraction of floor area for each benchmark. This approach attempts to most reasonably capture the floor space served by the various equipment types. For most building types, the most typical classes of equipment/systems, expressed in terms of fraction of buildings served, match the most common classes of equipment/systems in terms of floor space served, and the choice of selection method is not important. In both the pre-1980 and post-1980 buildings there are three notable exceptions: primary schools, secondary schools, and hotels.

\subsection{In Post-1980 Buildings}

In primary schools, the most common heating system by number of buildings is furnace. However, the most common heating system by floor space is boiler.

In secondary schools, the most common heating system appears to be furnace; however, the nearly equal fraction of heat pump responses suggest that it could also be heat pump-depending on what fraction of the classification of the PHUs might be a heat pump versus a furnace. Additionally, heat pumps are shown as the most common equipment for cooling and the combination of all direct expansion equipment (heat pump and PACU) predominates over the hydronic system. However, in terms of floor space served the hydronic chiller/boiler systems appears dominant.

In hotels, individual space heaters and individual air conditioners are the most common in terms of number of buildings serviced, but boilers and chillers dominate hotels in terms of floor space served.

\subsection{In Pre-1980 Buildings}

In primary schools, the most common heating system by number of buildings is furnace. However, by floor space the most common heating system is boiler.

In secondary schools, the most common main heating system is furnace; however, boiler/hydronic systems clearly dominate floor space heating. For cooling systems, the most common system, individual air conditioners, have a slight edge over packaged air conditioning units in terms of number of buildings, but packaged air conditioners clearly dominate in terms of total floorspace served. Secondary schools also commonly use residential type AC for cooling. Note that each of these cooling system types are 
direct expansion systems, with the most important differences likely related to the fan energy use and the effective energy efficiency ratio (EER) due to different equipment standards as a function of equipment capacity and whether single or three-phase. In terms of floor space, the total amount of floor space served by DX systems is higher than that served by hydronic (chiller or district cooling) systems.

Finally, in hotels, individual space heaters and IRAC are the most common in terms of number of buildings serviced, but boilers and chillers dominate in terms of floor space served.

\subsection{PNNL Recommendations}

This section contains PNNL's recommendations for Post-1980 and Pre-1980 Referenc buildings. These Reference buildings are based on the review of the CBECS data, PNNL's interpretations of the most likely meaning of PHUs, the desire to lump hydronic systems (chiller/district cooling and boiler/district heating) together, and the desire to capture the most floor space served within benchmark categories.

Table 3. PNNL Recommendations for Post-1980 Buildings - HVAC Equipment

\begin{tabular}{clcc}
\hline & \multicolumn{1}{c}{ Type } & \multicolumn{2}{c}{ PNNL Recommendation } \\
\cline { 3 - 4 } Number & \multicolumn{1}{c}{ Heating } & Cooling \\
\hline 1 & Large Office & Boiler & Chiller \\
2 & Medium Office & Furnace & PACU \\
3 & Small Office & Furnace & PACU \\
4 & Warehouse & Furnace & PACU \\
5 & Stand-alone Retail & Furnace & PACU \\
6 & Reserved (strip mall) & NA & NA \\
7 & Primary School & Boiler & PACU \\
8 & Secondary School & Boiler & Chiller \\
9 & Grocery Store & Furnace & PACU \\
10 & Fast Food & Furnace & PACU \\
11 & Restaurant & Furnace & PACU \\
12 & Hospital & Boilers & Chillers \\
13 & Outpatient Health Care & Furnace & PACU \\
14 & Motel & ISH & IRAC \\
15 & Hotel & Boiler & Chiller \\
\hline PACU - Packaged Air Conditioning Unit & ISH - Individual Space Heater & \\
IRAC - Individual Room Air Conditioner & NA - Not Available & \\
\hline
\end{tabular}


Table 4. PNNL Recommendations for Pre-1980 Buildings - HVAC Equipment

\begin{tabular}{cllc}
\hline & \multicolumn{1}{c}{ Type } & \multicolumn{2}{c}{ PNNL Recommendation } \\
\cline { 3 - 4 } Number & \multicolumn{1}{c}{ Heating } & Cooling \\
\hline 1 & Large Office & Boiler & Chiller \\
2 & Medium Office & Furnace & PACU \\
3 & Small Office & Furnace & PACU \\
4 & Warehouse & Furnace & PACU \\
5 & Stand-alone Retail & Furnace & PACU \\
6 & Reserved (strip mall) & NA & NA \\
7 & Primary School & Boiler & PACU \\
8 & Secondary School & Boiler & PACU \\
9 & Grocery Store & Furnace & PACU \\
10 & Fast Food & Furnace & PACU \\
11 & Restaurant & Furnace & PACU \\
12 & Hospital & Boilers & Chillers \\
13 & Outpatient Health Care & Furnace & PACU \\
14 & Motel & ISH & IRAC \\
15 & Hotel & Boiler & Chiller \\
\hline PACU - Packaged Air Conditioning Unit & ISH - Individual Space Heater & \\
IRAC - Individual Room Air Conditioner & NA - Not Available & \\
\hline
\end{tabular}

PNNL also performed an extraction of heating and cooling equipment with the cooling equipment choices further disaggregated by whether or not the building had a VAV system. Unfortunately, CBECS does not state which cooling systems this response applies to within a building or how much of the building the VAV system covers. In addition, there is no information in CBECS to help directly indicate the fraction of floor space covered by air distribution systems that are multi-zone or single zone. PNNL assumed that, in most systems, a VAV response of "yes" implies a multi-zone system somewhere in the building (although there may be exceptions, as when VAV is used for building pressurization control in hospitals or laboratories).

The decision on whether or not to recommend a VAV system in a particular reference building is further complicated by the fact that VAV systems may be common in a building type, but not necessarily common in the "most typical" system in that building type (See footnotes to Tables 6 and 7 regarding schools, grocery stores, hospitals, outpatient healthcare, and hotels). When examining the "most typical" system one must decide whether to consider the CBECS categories independently or to presume that PACU also includes other direct expansion system types. PNNL first examined what fraction of the total building floor space is in buildings reporting the use of VAV systems. These results are shown in Table 5 .

Table 5 shows the relative fraction of floor space in each building type using a VAV. However, DOE recognized that when a given equipment type is specified as the "most representative" for that building type, the relative fraction of floor space using VAV as well as use that equipment type could be different from the Table 5 results. To examine this, for each building type, DOE did a separate analysis which examined the fraction of floor space served by VAV systems only those buildings which indicated that they were served by the equipment types identified in Table 3 and Table 4 (with the presumption that 
hydronic cooling could be classified as chiller and hydronic heating could be classified under boiler for the purpose of identifying the relative fraction of floor space using a VAV air distribution system). This subsequent analysis showed that even though the relative fraction of identified floor space using VAV or not using VAV for the defined equipment differed from the values in Table 5, the particular buildings types where the majority of the floor space indicated the use of VAV air distribution did not change.

Table 5. Total Floor Space in Buildings Reporting Use of VAV Systems

\begin{tabular}{|c|c|c|c|}
\hline Number & Type & $\begin{array}{c}\text { Post-1980 Fraction of } \\
\text { Floor space reported with } \\
\text { VAV }^{\text {(a) }}\end{array}$ & $\begin{array}{c}\text { Pre-1980 Fraction of } \\
\text { Floor space reported with } \\
\text { VAV }^{\text {(a) }}\end{array}$ \\
\hline 1 & Large Office & $84 \%$ & $71 \%$ \\
\hline 2 & Medium Office & $53 \%$ & $26 \%$ \\
\hline 3 & Small Office & $24 \%$ & $11 \%$ \\
\hline 4 & Warehouse & $22 \%$ & $12 \%$ \\
\hline 5 & Stand-alone Retail & $12 \%$ & $10 \%$ \\
\hline 6 & Reserved (strip mall) & NA & NA \\
\hline 7 & Primary School & $44 \%$ & $27 \%$ \\
\hline 8 & Secondary School & $70 \%$ & $40 \%$ \\
\hline 9 & Grocery Store & $31 \%$ & $8 \%$ \\
\hline 10 & Fast Food & $12 \%$ & $40 \%$ \\
\hline 11 & Restaurant & $28 \%$ & $19 \%$ \\
\hline 12 & Hospital & $95 \%$ & $67 \%$ \\
\hline 13 & Outpatient Health Care & $45 \%$ & $23 \%$ \\
\hline 14 & Motel & $13 \%$ & $8 \%$ \\
\hline 15 & Hotel & $50 \%$ & $34 \%$ \\
\hline
\end{tabular}

(a) Fraction of those responding to question

NA - Not Available

Unfortunately, the authors' experience is that two building types in particular, hospitals and hotels, commonly rely on multiple systems. Virtually all hospital buildings in the CBECS survey use VAV systems. However, hospitals are complicated buildings and multiple distribution system types are both likely and common. Patient areas commonly have FCUs with individual heating control. In other areas, such as operating areas, most systems are likely constant volume (CAV) systems or a single zone with fan control, primarily for pressurization issues. Multi-zone VAV systems, while likely prevalent for office areas, are less likely used elsewhere in the building. CBECS provides little guidance here. The 2003 ASHRAE Applications Handbook (Chapter 7) presents a good review of system designs and concerns for hospital buildings.

Hotels are similar to hospitals in that they typically use a variety of systems, but the individual room areas of the hotel are more likely to be served by FCUs, IRAC units (PTAC/packaged terminal heat pump (PTHP), or water loop heat pumps. Inspection of the CBECS “\% cooled by" data shows that only 3 of 19 post-1980 buildings that report the use a VAV system also report chillers as the main cooling type, and none indicate district cooling. Another 13 buildings show a smattering of DX equipment (IRAC, heat pumps, PACU, and even residential type AC units) as the main cooling type. Only 3 buildings report the "\% cooled by" central AC at all. Given this and the relative preponderance of hydronic (e.g., chiller boiler) systems in hotels, it seems prudent to consider other data sources for determining a typical distribution system for hotels. At this stage, PNNL recommends a multiple system type with FCUs to serve the residential spaces (let hotel rooms) and kitchens, and either FCUs or possibly a VAV system to serve lobby and other rooms. 
In addition, it is important to address whether the buildings predominantly use single- or multi-zone systems. As stated, this information is not in CBECS. For the 15 benchmark building categories, PNNL used "professional judgment" to decide on single- or multi-zone systems. Table 6 and Table 7 show PNNL's initial recommendations of system types based on the CBECS data, including assumptions on single- or multi-zone systems. Tables 6 and 7 are identical to Tables 3 and 4, but include an extra column for air distribution.

There are four differences between Tables 6 and 7: 1) use of PACU instead of chiller in pre-1980 secondary schools, 2) use of CAV instead of multi-zone VAV in pre-1980 secondary schools, 3) use of single-zone CAV instead of multi-zone VAV in medium office, and 4) use of FCU and multi-zone CAV in hotels. Because professional judgment forms the basis for choosing whether a single-zone or multizone distribution system is most representative, both situations are likely common in both vintages of buildings. DOE may choose to make an executive decision that would make the pre- and post-1980 benchmarks equipment and or system choices identical in all vintages.

Table 6. PNNL Recommendations for Post-1980 Buildings - HVAC Equipment and Air Distribution

\begin{tabular}{cllll}
\hline & & \multicolumn{3}{c}{ PNNL Recommendation } \\
\cline { 3 - 5 } Number & & Heating & \multicolumn{1}{c}{ Cooling } & \multicolumn{1}{c}{ Air Distribution } \\
\hline 1 & Large Office & Boiler & Chiller & MZ VAV \\
2 & Medium Office & Furnace & PACU & MZ VAV \\
3 & Small Office & Furnace & PACU & SZ CAV \\
4 & Warehouse & Furnace & PACU & SZ CAV \\
5 & Stand-alone Retail & Furnace & PACU & SZ CAV \\
6 & Reserved (strip mall) & NA & NA & NA \\
7 & Primary School & Boiler & PACU & CAV \\
8 & Secondary School & Boiler & Chiller & MZ VAV \\
9 & Grocery Store & Furnace & PACU & CAV \\
10 & Fast Food & Furnace & PACU & SZ CAV \\
11 & Restaurant & Furnace & PACU & SZ CAV \\
12 & Hospital & Boiler & Chiller & FCU, CAV and VAV \\
13 & Outpatient Health Care & Furnace & PACU & CAVV \\
14 & Motel & ISH & IRAC & SZ CAV \\
15 & Hotel & Boiler & Chiller & FCU and VAV \\
\hline
\end{tabular}

(a) Unclear if single zone or multi-zone

(b) Hospitals may utilize CV systems in some operating and critical care type areas with variable air flow used for pressurization, but classic VAV multi-zone systems in other areas like offices. CBECS guidance seems limited here and other sources should be consulted.

(c) Hotels may be characterized with two system types serving different areas. Both multizone systems (VAV or CAV) may serve public spaces (lobby/conference rooms), whereas single zone fan coil systems may be common for living areas. In some hotels, some amount of multi-step or continuous fan control for these fan coils may also exist.

PACU - packaged air conditioning unit $\quad$ ISH - individual space heater

IRAC - individual room air conditioner $\quad$ SZ - single zone

MZ - multi-zone

$\mathrm{CAV}$ - constant air volume

VAV - variable air volume

FCU - fan coil unit

NA - not available 
Table 7. PNNL Recommendations for Pre-1980 Buildings - HVAC Equipment and Air Distribution (bold italic text shows differences from post-1980 recommendations)

\begin{tabular}{cllll}
\hline & & \multicolumn{2}{c}{ PNNL Recommendation } \\
\cline { 3 - 5 } Number & & Heating & \multicolumn{1}{c}{ Cooling } & \multicolumn{1}{c}{ Air Distribution } \\
\hline 1 & Large Office & Boiler & Chiller & MZ VAV \\
2 & Medium Office & Furnace & PACU & S $\boldsymbol{C} \boldsymbol{A} \boldsymbol{V}$ \\
3 & Small Office & Furnace & PACU & SZ CAV \\
4 & Warehouse & Furnace & PACU & SZ CAV \\
5 & Stand-alone Retail & Furnace & PACU & SZ CAV \\
6 & Reserved (strip mall) & NA & NA & NA \\
7 & Primary School & Boiler & PACU & CAV $^{(\text {a) }}$ \\
8 & Secondary School & Boiler & PACU & $\boldsymbol{C A V}^{(\text {a) }}$ \\
9 & Grocery Store & Furnace & PACU & CAV $^{(a)}$ \\
10 & Fast Food & Furnace & PACU & SZ CAV \\
11 & Restaurant & Furnace & PACU & SZ CAV \\
12 & Hospital & Boiler & Chiller & FCU, CAV and VAV \\
13 & Outpatient Health Care & Furnace & PACU & CAV \\
14 & Motel & ISH & IRAC & SZ CAV \\
15 & Hotel & Boiler & Chiller & $\boldsymbol{F C U}$ and $\boldsymbol{M} \boldsymbol{Z} \boldsymbol{C A}^{(\mathbf{c})}$ \\
\hline
\end{tabular}

(a) Unclear if single zone or multi-zone

(b) Hospitals may utilize CV systems in some operating and critical care type areas with variable air flow used for pressurization, but classic VAV multi-zone systems in other areas like offices. CBECS guidance seems limited here and other sources should be consulted. CBECS Buildings reporting VAV are significantly less common in pre- 1980 buildings ( $67 \%$ versus $95 \%$ in post- 1980 hospitals).

(c) Hotels may be characterized with two system types serving different areas. Both multi-zone systems (VAV or CAV) may serve public spaces (lobby/conference rooms), whereas single zone fan coil systems may be common for living areas.

Bold Italics - Indicates pre-1980 recommendations that are different from post-1980 recommendations.

PACU - packaged air conditioning unit

ISH - individual space heater

IRAC - individual room air conditioner

$\mathrm{SZ}$ - single zone

MZ - multi-zone

$\mathrm{VAV}$ - variable air volume

CAV - constant air volume

$\mathrm{NA}$ - not available

FCU - fan coil units

\subsection{References}

DOE EIA 1995. 1995 Commercial Building Energy Consumption Survey. DOE Energy Information Administration. Washington, DC. All released data on the 1995 CBECS may be found at http://www.eia.doe.gov/emeu/cbecs/.

DOE IEA 2003. 2003 Commercial Building Energy Consumption Survey . DOE Energy Information Administration. Washington, DC. All released data on the 2003 CBECS may be found at http://www.eia.doe.gov/emeu/cbecs/. 




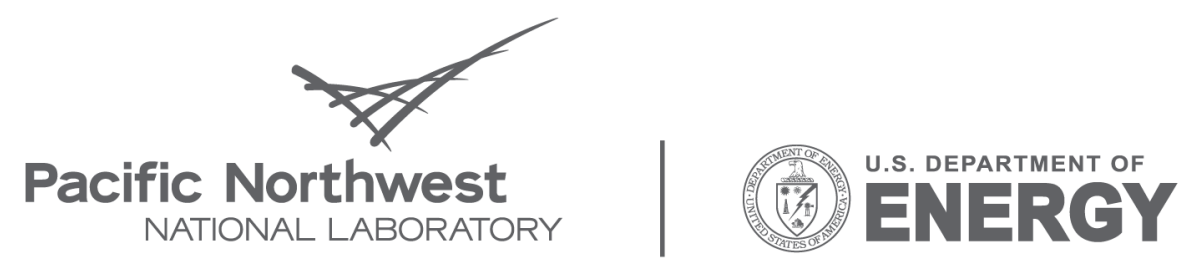

Proudly Operated by Battelle Since 1965

902 Battelle Boulevard

P.O. Box 999

Richland, WA 99352

1-888-375-PNNL (7665)

www.pnl.gov 